\title{
Communication \\ Monoterpenoids from the Fruits of Amomum tsao-ko Have Inhibitory Effects on Nitric Oxide Production
}

\author{
Seong Su Hong $1, * \mathbb{1}$, Ji Eun Lee ${ }^{1}$, Yeon Woo Jung ${ }^{1}$, Ju-Hyoung Park ${ }^{2}$, Jung A. Lee ${ }^{1}$, Wonsik Jeong ${ }^{1}$, \\ Eun-Kyung Ahn ${ }^{1}$, Chun Whan Choi ${ }^{1}$ and Joa Sub Oh ${ }^{2, *}$ \\ 1 Bio-Center, Gyeonggido Business \& Science Accelerator (GBSA), Suwon 16229, Korea; \\ jieun@gbsa.or.kr (J.E.L.); jion123@gbsa.or.kr (Y.W.J.); lovelee90@gbsa.or.kr (J.A.L.); ws2009@gbsa.or.kr (W.J.); \\ aek@gbsa.or.kr (E.-K.A.); cwchoi@gbsa.or.kr (C.W.C.) \\ 2 College of Pharmacy, Dankook University, Cheonan 31116, Korea; yourselves@naver.com \\ * Correspondence: bestgene@gbsa.or.kr (S.S.H.); jsoh@dankook.ac.kr (J.S.O.); Tel.: +82-31-888-6120 (S.S.H.); \\ +82-41-550-1435 (J.S.O.)
}

Citation: Hong, S.S.; Lee, J.E.; Jung, Y.W.; Park, J.-H.; Lee, J.A.; Jeong, W.; Ahn, E.-K.; Choi, C.W.; Oh, J.S. Monoterpenoids from the Fruits of Amomum tsao-ko Have Inhibitory Effects on Nitric Oxide Production. Plants 2021, 10, 257. https://doi.org/ $10.3390 /$ plants10020257

Academic Editors: Laura Cornara and Antonella Smeriglio

Received: 22 December 2020

Accepted: 25 January 2021

Published: 28 January 2021

Publisher's Note: MDPI stays neutral with regard to jurisdictional claims in published maps and institutional affiliations.

Copyright: (c) 2021 by the authors. Licensee MDPI, Basel, Switzerland. This article is an open access article distributed under the terms and conditions of the Creative Commons Attribution (CC BY) license (https:/ / creativecommons.org/licenses/by/ $4.0 /)$.

\begin{abstract}
In our search for novel plant-derived inhibitors of nitric oxide (NO) with potential for treating inflammatory diseases, the phytochemicals of Amomum tsao-ko fruits were investigated, leading to the isolation of one bicyclic nonane (1), three menthene skeleton monoterpenoids (2-4), and two acyclic monoterpenoids (5 and 6). Their structures were identified using one- and twodimensional nuclear magnetic resonance spectroscopy, and mass spectrometry. To the best of our knowledge, compounds 2-5 were obtained from the genus Amomum for the first time. All isolates were tested for their ability to inhibit lipopolysaccharide-stimulated $\mathrm{NO}$ overproduction in RAW264.7 cells. Compound 4 was found to inhibit NO production. Western blotting analysis indicated that active compound 4 can regulate inducible NO synthase expression. In addition, lipopolysaccharide-induced interleukin 1 beta and interleukin- 6 overproduction was reduced in a concentration-dependent manner.
\end{abstract}

Keywords: Amomum tsao-ko; monoterpenoid; anti-inflammation; nitric oxide; menthene skeleton

\section{Introduction}

Bioactive natural resources played a vital roles in the discovery and development of new pharmaceuticals, and many lead constituents are derived from natural products or their derivatives [1]. Plant secondary metabolites are considered an important source of bioactive natural products [2]. Amomum is the second largest genus in the Zingiberaceae family, comprising at least 170 species distributed across southeast Asia and northern Australia, in the Afrotropical region of Africa, the Himalayas, and the Central Pacific [3,4]. A perennial herb, Amomum tsao-ko Crevost and Lemarié, is used as a food additive (traditional Chinese spice) and medicine [5,6]. Its dried fruit is commonly used to treat abdominal pain, dyspepsia, malaria, nausea, throat infections, stomach disorders, vomiting, and diarrhea in the traditional medicine system [7]. Because of their numerous pharmacological activities, such as antitumor, antioxidant, and neuroprotective properties, the fruits of A. tsao-ko have attracted attention as a functional food and medicine [8-12]. The major constituents of $A$. tsao-ko are diarylheptanoid and flavonoids, which exhibit anti-oxidant, anti-tumor, anti-inflammatory and $\alpha$-glucosidase inhibitory activities, neuroprotective effects, and nitric oxide (NO) inhibitory effects [13-15]. Inflammation is the immune system's biological response for removing harmful stimuli and repairing damaged tissue caused through harmful factors, such as damaged cells, invasion by pathogens, irradiation or, toxic compounds [16]. When inflammation happens, the endotoxin lipopolysaccharide (LPS), produced by gram-negative bacteria, induces the expression of inducible nitric oxide synthase (iNOS), which produce excessive NO [17]. LPS also induces the release of pro-inflammatory cytokines including interleukin (IL)-1 $\beta$ and IL- 6 which cause tissue 
damage and organ failure [18]; regulating these cytokines could be a therapeutic strategy for addressing various inflammatory-associated diseases. Four menthene skeleton monoterpenoids and two acyclic monoterpenoids from $A$. tsao-ko fruits have been identified as a part of an ongoing project to discover anti-inflammatory metabolites in functional plants. In LPS-induced murine macrophage RAW264.7 cells, all compounds were preliminarily screened for the ability to prevent NO production, with mechanistic studies revealing $(1 R, 4 S, 6 S)$-1,6-dihydroxy-2-menthene (4) to be a significant anti-inflammatory constituent. In this study, we performed isolation, structural determination, and anti-inflammatory activity analysis of the isolated compounds.

\section{Results and Discussion}

\subsection{Chemical Characterization}

\subsubsection{Isolation Compounds}

The dried fruits of $A$. tsao-ko were divided via sequential extraction with $\mathrm{CH}_{2} \mathrm{Cl}_{2}$ (n-hexane and $50 \%$ methanol (MeOH) layer), ethyl acetate, and $n$-butyl alcohol. Of the four solvent soluble fractions, the $50 \% \mathrm{MeOH}$ fraction was performed to successive column chromatography with silica gel, medium-pressure liquid chromatography (MPLC), and preparative high-performance liquid chromatography (HPLC) to yield six compounds (Figure 1).

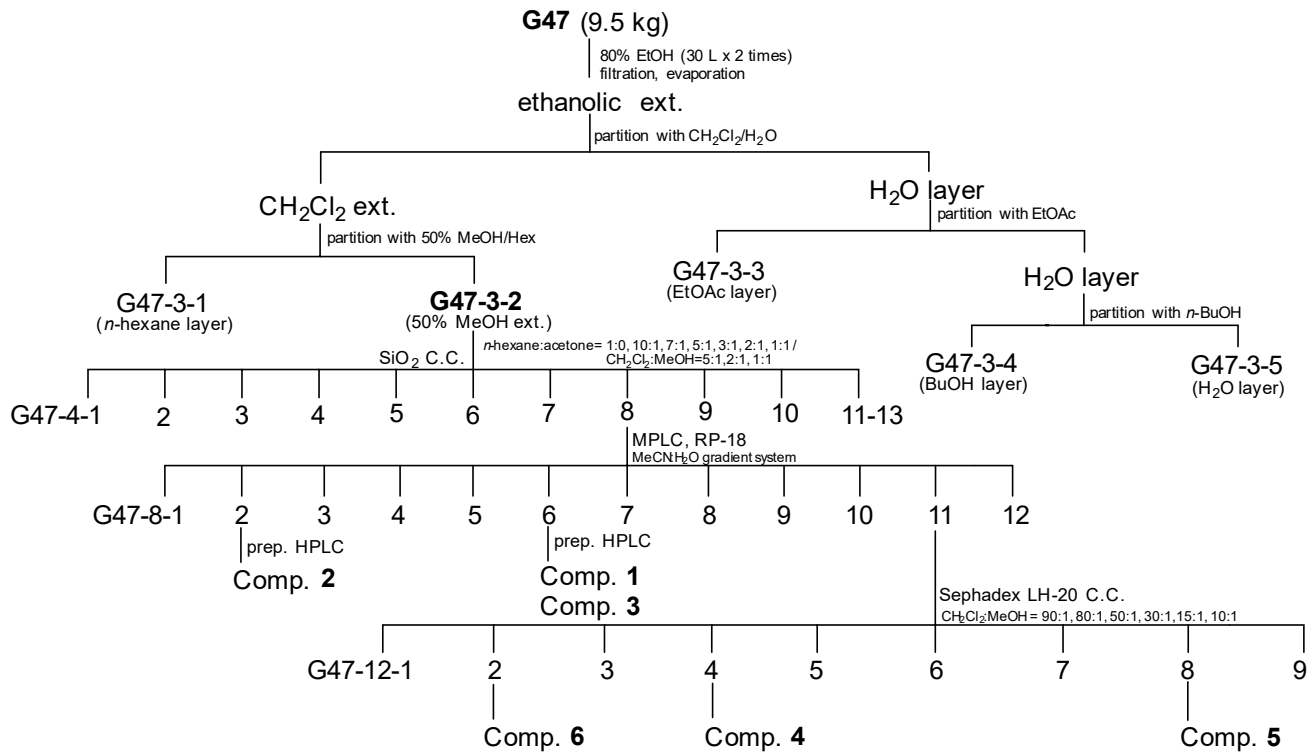<smiles>O=CC1=CCC(O)C2CCCC12</smiles>

1<smiles>CC(C)C1C=C[C@](C)(O)C(O)C1</smiles>

4<smiles>CC1=CC(O)C(=C(C)C)CC1O</smiles>

2<smiles>CC(=CCO)CC[C@H](C)CO</smiles>

5<smiles>C=C(C)C1CC[C@](C)(O)C[C@H]1O</smiles>

3<smiles>CC(C=O)=CCCC(C)=CCO</smiles>

6

Figure 1. Fractionation flow map and structure of compounds isolated from the fruits of A. tsao-ko. 


\subsubsection{Identification of Compound Structures}

Compound 1 was obtained as a pale brown oil. A molecular ion peak at $m / z 167$ $[\mathrm{M}+\mathrm{H}]^{+}$was observed via electrospray ionization-mass spectrometry (ESI-MS) (positive ion mode). The ${ }^{1} \mathrm{H}$ (Figure S2), ${ }^{13} \mathrm{C}$ (Figure S3), and distortionless enhancement by polarization transfer (DEPT) nuclear magnetic resonance (NMR) spectra of 1 displayed a signal assignable to an aldehyde group $\left[\delta_{\mathrm{H}} 9.42(1 \mathrm{H}, \mathrm{s}, \mathrm{H}-10) ; \delta_{\mathrm{C}} 194.0\right]$ and trisubstituted olefin $\left[\delta_{\mathrm{H}} 6.66(\mathrm{~s}, \mathrm{H}-3) ; \delta_{\mathrm{C}} 144.8(\mathrm{C}-2)\right.$ and $\left.146.7(\mathrm{C}-3)\right]$. The ${ }^{13} \mathrm{C}$ NMR and DEPT spectra indicated the presence of four methylenes $\left(\delta_{C} 32.2,31.2,24.9\right.$, and 24.7$)$, two methines $\left(\delta_{C}\right.$ 42.8 and 37.2$)$, one oxymethine $\left(\delta_{C} 68.4\right)$, and an aldehyde group and double bond (Table 1$)$. Compound 1's NMR data were consistent with the spectral data in the literature [19]; thus, compound 1 was identified as tsaokoin, a bicyclic nonane derivative.

Table 1. ${ }^{13} \mathrm{C}$ NMR spectroscopic data of $\mathbf{1 - 6}\left(\delta \text { in ppm, } 175 \mathrm{MHz} \text {, in } \mathrm{CDCl}_{3}\right)^{a}$.

\begin{tabular}{ccccccc}
\hline Position & $\mathbf{1}$ & $\mathbf{2}^{\boldsymbol{b}}$ & $\mathbf{3}$ & $\mathbf{4}$ & $\mathbf{5}$ & $\mathbf{6}$ \\
\hline 1 & $37.2 \mathrm{~d}^{c}$ & $137.4 \mathrm{~s}$ & $71.4 \mathrm{~s}$ & $69.1 \mathrm{~s}$ & $59.4 \mathrm{t}$ & $59.3 \mathrm{t}$ \\
2 & $144.8 \mathrm{~s}$ & $131.0 \mathrm{~d}$ & $46.1 \mathrm{t}$ & $132.1 \mathrm{~d}$ & $123.4 \mathrm{~d}$ & $124.5 \mathrm{~d}$ \\
3 & $146.7 \mathrm{~d}$ & $69.9 \mathrm{~d}$ & $67.3 \mathrm{~d}$ & $134.1 \mathrm{~d}$ & $139.9 \mathrm{~s}$ & $137.9 \mathrm{~s}$ \\
4 & $31.2 \mathrm{t}$ & $42.8 \mathrm{~d}$ & $54.0 \mathrm{~d}$ & $42.6 \mathrm{~d}$ & $39.7 \mathrm{t}$ & $37.8 \mathrm{t}$ \\
5 & $68.4 \mathrm{~d}$ & $30.9 \mathrm{t}$ & $25.3 \mathrm{t}$ & $30.1 \mathrm{t}$ & $24.9 \mathrm{t}$ & $27.1 \mathrm{t}$ \\
6 & $42.8 \mathrm{~d}$ & $68.4 \mathrm{~d}$ & $38.1 \mathrm{t}$ & $73.6 \mathrm{~d}$ & $32.6 \mathrm{t}$ & $153.7 \mathrm{~d}$ \\
7 & $24.7 \mathrm{t}$ & $20.7 \mathrm{q}$ & $31.7 \mathrm{q}$ & $25.9 \mathrm{q}$ & $35.6 \mathrm{~d}$ & $139.6 \mathrm{~s}$ \\
8 & $24.9 \mathrm{t}$ & $27.0 \mathrm{~d}$ & $146.3 \mathrm{~s}$ & $31.5 \mathrm{~d}$ & $68.3 \mathrm{t}$ & $195.3 \mathrm{~d}$ \\
9 & $32.2 \mathrm{t}$ & $21.4 \mathrm{q}$ & $113.1 \mathrm{t}$ & $19.6 \mathrm{q}$ & $16.2 \mathrm{q}$ & $16.3 \mathrm{q}$ \\
10 & $194.0 \mathrm{~d}$ & $17.0 \mathrm{q}$ & $19.3 \mathrm{q}$ & $19.0 \mathrm{q}$ & $16.5 \mathrm{q}$ & $9.3 \mathrm{q}$ \\
\hline
\end{tabular}

${ }^{a}$ Assignments were confirmed by 1D and 2D NMR data. ${ }^{b}$ Data were measured in methanol- $d_{4} .{ }^{c}$ Carbon multiplicity deduced by DEPT and HSQC.

As a colorless oil, compound 2 was isolated with a molecular weight of the quasimolecular ion peak at $m / z 171[\mathrm{M}+\mathrm{H}]^{+}$, based on the ESI-MS data. The ${ }^{1} \mathrm{H}$ NMR (Figure S4) data suggested $\mathrm{H}-2$ as a singlet at $\delta_{\mathrm{H}} 5.49 ; \mathrm{H}-6, \mathrm{H}-3$, and $\mathrm{H}-4$ signals appeared at $\delta_{\mathrm{H}} 3.94$ (brs), $3.87(\mathrm{~d}, J=9.1 \mathrm{~Hz})$, and $1.61(\mathrm{~m})$, respectively; an isopropyl group at $\delta_{\mathrm{H}} 2.14(\mathrm{~m}, \mathrm{H}-8)$, $1.00(\mathrm{~d}, J=7.0 \mathrm{~Hz}, \mathrm{Me}-9)$, and $0.85(\mathrm{~d}, J=7.0 \mathrm{~Hz}, \mathrm{Me}-10)$; and vinylic methyl signal at $\delta_{\mathrm{H}}$ 1.79 (s, Me-7). The data revealed that compound 2 was a monoterpenoid based on the skeleton of menthene [20]. Ten signals were detected via ${ }^{13} \mathrm{C}$ NMR (Figure S5) and DEPT: vinyl carbon signals $C-1$ and $C-2$ at $\delta_{C} 137.4$ and 131.0, respectively; two oxymethines at $\delta_{C} 69.9(\mathrm{C}-3)$ and $68.4(\mathrm{C}-6)$; three methyls at $\delta_{C} 20.7(\mathrm{C}-7), 21.4(\mathrm{C}-9)$, and $17.0(\mathrm{C}-10)$; one methylene at $\delta_{C} 30.9(\mathrm{C}-5)$; and two methine signals at $\delta_{C} 42.8(\mathrm{C}-4)$ and $27.0(\mathrm{C}-8)$ (Table 1). The NMR results for compound 2 were compatible with the spectral data in the literature [21]; thus, compound 2 was identified as (3S,4S,6R)-3,6-dihydroxy-1-menthene.

Compound 3 was obtained as a pale yellowish oil. A positive ESI-MS experiment exhibited a quasi-molecular ion peak at $m / z 171[\mathrm{M}+\mathrm{H}]^{+}$. The data of ${ }^{1} \mathrm{H}$ NMR (Figure S6) indicated $\mathrm{H}-9$ as an exo-methylene singlet signals at $\delta_{\mathrm{H}} 4.94$ and 4.90 ; an oxygenated proton $\delta_{\mathrm{H}} 3.84(\mathrm{~d}, \mathrm{~J}=10.5,4.9 \mathrm{~Hz}, \mathrm{H}-3)$; and two methyl signals $\delta_{\mathrm{H}} 1.76\left(\mathrm{~s}, \mathrm{CH}_{3}-10\right)$ and $\delta_{\mathrm{H}}$ 1.30 (s, $\left.\mathrm{CH}_{3}-7\right)$. The ${ }^{13} \mathrm{C}$ NMR (Figure S7) and DEPT spectra showed 10 signals: $\mathrm{C}-8$ and C-9 exo-methylene carbon signals at $\delta_{C} 146.3$ and 113.1; an oxymethine at $\delta_{C} 67.3(\mathrm{C}-3)$; oxygenated quaternary carbon at $\delta_{C} 71.4(\mathrm{C}-1)$; two methyls at $\delta_{C} 31.7(\mathrm{C}-7)$ and $19.3(\mathrm{C}-10)$; three methylenes at $\delta_{C} 46.1(\mathrm{C}-2), 38.1(\mathrm{C}-6)$, and $25.3(\mathrm{C}-5)$; and one methine signal at $\delta_{C}$ 54.0 (C-4) (Table 1). The NMR results for compound 3 was consistent with the spectral data in the literature [22]; thus, compound 3 were determined as $(1 R, 3 S, 4 R)$-3-hydroxy isopulegol.

Compound 4 was isolated as a pale yellowish oil. The molecular weight of compound 4 was obtained via ESI-MS with $m / z 171[\mathrm{M}+\mathrm{H}]^{+}$. The ${ }^{1} \mathrm{H}$ (Figure S8) and ${ }^{13} \mathrm{C}$ NMR (Figure S9) spectroscopic data were similar to those of compound 2, indicating that they have similar structures. The ${ }^{1} \mathrm{H}$ NMR data indicated $\mathrm{H}-2$ and $\mathrm{H}-3$ as a pair olefinic double bond with signals at $\delta_{\mathrm{H}} 5.71(2 \mathrm{H}, \mathrm{m})$; oxygenated proton $\delta_{\mathrm{H}} 3.49$ (brd, $\left.J=12.6 \mathrm{~Hz}, \mathrm{H}-6\right)$; isopropyl group at $\delta_{\mathrm{H}} 1.70(\mathrm{~m}, \mathrm{H}-8), 0.94(\mathrm{~d}, J=7.0 \mathrm{~Hz}, \mathrm{Me}-9)$, and $0.91(\mathrm{~d}, J=7.0 \mathrm{~Hz}$, 
Me-10); and methyl group at $\delta_{\mathrm{H}} 1.36$ (s, Me-7). The ${ }^{13} \mathrm{C}$ NMR and DEPT spectra showed 10 signals: C-3 and C-2 olefinic double bond signals at $\delta_{C} 134.1$ and 132.1, respectively; oxymethine at $\delta_{C} 73.6(\mathrm{C}-6)$; oxygenated quaternary carbon at $\delta_{C} 69.1$ (C-1); three methyls at $\delta_{C} 25.9(\mathrm{C}-7), 19.6(\mathrm{C}-9)$, and $19.0(\mathrm{C}-10)$; one methylene at $\delta_{C} 30.1$ (C-5); and two methine signals at $\delta_{C} 42.6$ (C-4) and 31.5 (C-8) (Table 1). The NMR data of compound 4 were consistent with the spectral data in the literature [23]; thus, compound 4 was determined as $(1 R, 4 S, 6 S)$-1,6-dihydroxy-2-menthene.

Compound 5 was obtained as a colorless oil. The molecular weight of compound 5 was observed via ESI-MS with $m / z 173[\mathrm{M}+\mathrm{H}]^{+}$. The ${ }^{1} \mathrm{H}$ NMR (Figure S10) data indicated $\mathrm{H}-2$ as a double bond at $\delta_{\mathrm{H}} 5.43(\mathrm{t}, J=6.3 \mathrm{~Hz})$; two oxymethylene protons at $\delta_{\mathrm{H}} 4.17(\mathrm{~d}$, $\left.J=6.3 \mathrm{~Hz}, \mathrm{H}_{2}-1\right), 3.52\left(\mathrm{~d}, J=10.5,6.3 \mathrm{~Hz}, \mathrm{H}_{\mathrm{a}}-8\right)$, and $3.46\left(\mathrm{~d}, J=9.8,6.3 \mathrm{~Hz}, \mathrm{H}_{\mathrm{b}}-8\right)$; olefinic methyl group at $\delta_{\mathrm{H}} 1.69\left(\mathrm{~s}, \mathrm{CH}_{3}-9\right)$; and tertiary methyl group at $\delta_{\mathrm{H}} 0.94(\mathrm{~d}, J=7.0 \mathrm{~Hz}$, $\mathrm{CH}_{3}-10$ ). The ${ }^{13} \mathrm{C}$ NMR (Figure S11) and DEPT spectra showed 10 signals: C-3 and C-2 olefinic carbon signals at $\delta_{C} 139.9$ and 123.4 , respectively; two oxymethylenes at $\delta_{C} 68.3$ $(\mathrm{C}-8)$ and 59.4 (C-1); two methyl signals at $\delta_{C} 16.5(\mathrm{C}-10)$ and 16.2 (C-9); three methylene carbons at $\delta_{C} 39.7(\mathrm{C}-4), 32.6(\mathrm{C}-6)$, and $24.9(\mathrm{C}-5)$; and one methine signal at $\delta_{\mathrm{C}} 35.6$ (C-7) (Table 1). The NMR spectral data of compound 5 agreed with those reported in the literature [24]; thus, compound 5 was identified as 3,7-dimethyl-2-octene-1,8-diol.

Compound $\mathbf{6}$ was isolated as a colorless oil with a molecular weight of a quasimolecular ion peak at $m / z 169[\mathrm{M}+\mathrm{H}]^{+}$, based on the ESI-MS data. The ${ }^{1} \mathrm{H}$ NMR (Figure S12) data indicated H-2 and H-6 as a double bond at $\delta_{\mathrm{H}} 5.39(\mathrm{t}, J=7.0 \mathrm{~Hz})$ and 6.40 $(\mathrm{t}, J=7.0 \mathrm{~Hz})$, respectively; aldehyde singlet at $\delta_{\mathrm{H}} 9.32(\mathrm{~s}, \mathrm{H}-8)$; oxymethylene signal at $\delta_{\mathrm{H}}$ $4.12\left(\mathrm{~d}, J=7.0 \mathrm{~Hz}, \mathrm{H}_{2}-1\right)$; and two vinylic methyl groups at $\delta_{\mathrm{H}} 1.68\left(\mathrm{~s}, \mathrm{CH}_{3}-10\right)$ and $1.63(\mathrm{~s}$, $\mathrm{CH}_{3}-9$ ). The ${ }^{13} \mathrm{C}$ NMR (Figure S13) and DEPT spectra showed 10 signals: $\mathrm{C}-6, \mathrm{C}-7, \mathrm{C}-3$, and C-2 vinylic carbon signals at $\delta_{C} 153.7,139.6,137.9$ and 124.5 , respectively; aldehyde group at $\delta_{C} 195.3(\mathrm{C}-8)$; oxymethylene at $\delta_{C} 59.3$ (C-1); two methyl groups at $\delta_{C} 16.3(\mathrm{C}-9)$ and 9.3 (C-10); and two methylenes at $\delta_{C} 37.8$ (C-4) and 27.1 (C-5) (Table 1). The MS and NMR data of compound 6 agreed well with those reported in the literature [25]; thus, compound 6 was identified as 8-oxogeraniol.

\subsection{Nitric Oxide Inhibition Activity and Cell Viability}

To obtain plant-derived inhibitors of NO as potential lead compounds for treating inflammation disorders, monoterpene constituents 1-6 isolated from the fruits of $A$. tsao-ko were assayed to determine their inhibitory activities on LPS-induced NO production in murine macrophage RAW 264.7 cells via the Griess reaction assay, as described previously [26]. The $\mathrm{IC}_{50}$ value of NG-methyl-L-arginine acetate used as a positive control was $34.2 \mu \mathrm{M}$. All isolates were tested for their inhibitory effects on LPS-induced NO generation and the $\mathrm{IC}_{50}$ values were included in Table 2 . Based on their $\mathrm{IC}_{50}$ values, compound 4 moderately inhibited toward LPS-mediated NO overproduction, with an $\mathrm{IC}_{50}$ values of $82.5 \mu \mathrm{M}$, whereas the other constituents showed essentially no efficacy (Table 2 and Figure S1). Cell viability was evaluated via the (3-(4,5-dimethylthiazol-2-yl)-2,5-diphenyltetrazolium bromide (MTT) assay. All compounds exhibited no cytotoxicity at effective concentration for inhibiting NO production in LPS-stimulated macrophage cells (Table 2).

Table 2. Inhibitory effects of isolated compounds on LPS-induced NO production in RAW 264.7 cells.

\begin{tabular}{|c|c|c|}
\hline Compound & $\mathrm{IC}_{50}(\mu \mathrm{M})^{a}$ & $\operatorname{MTT}(\mu \mathrm{M})$ \\
\hline tsaokoin $(\mathbf{1})$ & $>100$ & $>100$ \\
\hline$(3 S, 4 S, 6 R)$-3,6-dihydroxy-1-menthene (2) & $>100$ & $>100$ \\
\hline$(1 R, 3 S, 4 R)-3$-hydroxy isopulegol (3) & $>100$ & $>100$ \\
\hline$(1 R, 4 S, 6 S)$-1,6-dihydroxy-2-menthene (4) & 82.5 & $>100$ \\
\hline 3,7-dimethyl-2-octene-1,8-diol (5) & $>100$ & $>100$ \\
\hline 8-oxogeraniol (6) & $>100$ & $>100$ \\
\hline NG-methyl-L-arginine acetate ${ }^{b}$ & 34.2 & $>100$ \\
\hline
\end{tabular}

${ }^{a} \mathrm{IC}_{50}$ represents the concentration of an inhibitor required for half maximal inhibition. ${ }^{b}$ NG-methyl-L-arginine acetate was used as a positive control. 


\subsection{Evaluation of iNOS Protein Expression and Pro-Inflammatory Cytokine mRNA Expressions}

L-Arginine-derived NO is an intracellular signaling molecule formed in mammalian cells by different three isoforms of nitric oxide synthase (NOS). The isozymes are referred to as neuronal NOS (nNOS or NOS I), inducible NOS (iNOS or NOS II), and an endothelial NOS (eNOS or NOS III) [27]. Excessive generation of NO by iNOS is seen in inflammatory diseases such as autoimmune and chronic inflammatory disorders [28]. To examine the mechanism of NO inhibition by active compound 4, we evaluated iNOS protein expression via western blotting. As shown in Figure 2A,B, treatment of RAW264.7 cells with LPS $(1 \mu \mathrm{g} / \mathrm{mL})$ remarkably increased iNOS expression. However, pretreatment with compound 4 significantly and dose-dependently inhibited iNOS expression.

(A)

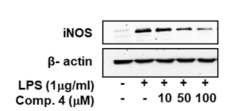

(D)

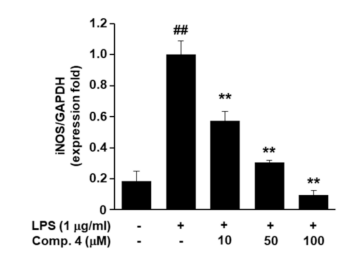

(B)

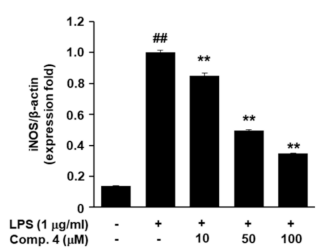

(C)
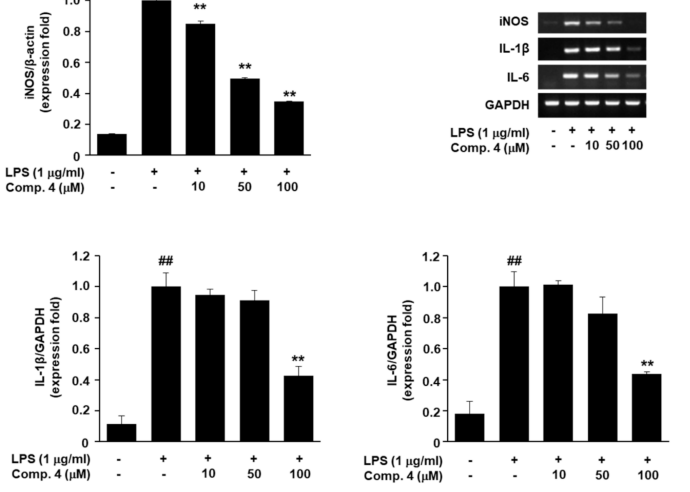

Figure 2. Effects of $(1 R, 4 S, 6 S)$-1,6-dihydroxy-2-menthene (compound 4) on iNOS protein and proinflammatory cytokine mRNA expression in LPS-stimulated RAW264.7 cells. RAW264.7 cells were pretreated with different concentrations $(10,50,100 \mu \mathrm{M})$ of compound 4 for $1 \mathrm{~h}$, and then stimulated with $1 \mu \mathrm{g} / \mathrm{mL}$ LPS for $24 \mathrm{~h}$. (A,B) Western blot analysis of iNOS expression in cells treated with compound $4(10,50,100 \mu \mathrm{M})$. $\beta$-Actin was used as a loading control. (C,D) Levels of iNOS, IL$1 \beta$, and IL- 6 mRNAs were determined via RT-PCR. RT-PCR data results were expressed as the fold of changes of the target gene (iNOS, IL-1 $\beta$, and IL-6) and normalized to the GAPDH. Values represent the mean \pm SD of three independent experiments. Statistical significance is indicated (\#\# $p<0.01$ compared to the untreated control/LPS (-), while ${ }^{* *} p<0.01$, compared to LPS-treated cells group/LPS $(+))$.

Next, we confirmed the effect of compound 4 on the expression of inflammatory factors, i.e., iNOS, IL-1 $\beta$, and IL-6 in LPS-stimulated RAW264.7 cells. IL-1 $\beta$ and IL-6 are the most important pro-inflammatory cytokines in an inflammatory response. The inhibition of pro-inflammatory cytokine, such as IL- $1 \beta$ and IL- 6 is essential for the control of an inflammatory response [29]. We measured the levels of the relevant mRNAs via reverse transcription polymerase chain reaction (RT-PCR) [30]. Like the iNOS protein expression result, compound 4 treatment decreased the iNOS expression at the mRNA level, in a dose-dependent manner. And reduced IL- $1 \beta$ and IL-6 mRNA level (Figure 2C,D). These results of the experiment with RT-PCR need to be verified through Real-time PCR in order to measure the expression level more correctly in the further study [31].

A. tsao-ko is an active, traditional herb medicine used to treat various inflammatory diseases [32]. The present study was undertaken to elucidate the pharmacological active molecule from the fruits of $A$. tsao-ko on the production of inflammatory mediators in macrophages. We showed that $(1 R, 4 S, 6 S)-1,6$-dihydroxy-2-menthene (4) isolated from A. tsao-ko suppressed the production of NO, iNOS, IL-1 $\beta$, and IL-6 in LPS-stimulated RAW264.7 cells, which are primary peritoneal macrophages. This suppression correlated with downregulated gene expression of IL- $1 \beta$, IL-6, and, iNOS. NO, which are produced by iNOS, have been implicated as important mediators in endotoxemia and inflammatory conditions. However, although the anti-inflammatory effects of $(1 R, 4 S, 6 S)$-1,6-dihydroxy- 
2-menthene (4) were identified, their exact mechanism of action was not determined. Thus, the active constituent can be further studied for their possible inhibitory mechanism toward the proinflammatory cytokines as well as they can be tested in the in vivo inflammatory models.

\section{Materials and Methods}

\subsection{General}

The optical rotations were measured with a JASCO P-2000 polarimeter (Tokyo, Japan). 1D and 2D NMR experiments were conducted on a Bruker Ascend III 700 instrument (Bruker-Biospin, Karlsruhe, Germany) with tetramethylsilane as an internal reference; chemical shifts are expressed in $\delta$ values. ESI masses were acquired on a LTQ Orbitrap XL mass spectrometer (Thermo Fisher Scientific, Waltham, MA, USA). MPLC (Teledyne ISCO, Lincoln, NE, USA) separations were carried out on a RediSep ${ }^{\circledR}$ Rf column (Teledyne ISCO, Lincoln, NE, USA). Preparative HPLC was conducted on an LC-8A chromatography system (two LC-8A solvent delivery unit, an SPD-M20A photodiode array detector, and a CBM20A communication module; Shimadzu, Kyoto, Japan) and J'sphere ODS-H80 column (4 $\mu \mathrm{m}, 250 \times 20 \mathrm{~mm}$, YMC Corp., Kyoto, Japan). The SPECTRAmax system was used as an ELISA reader (Molecular Devices, Sunnyvale, CA, USA). Thin layer chromatography (TLC) was carried out using ALUGRAM ${ }^{\circledR}$ SIL G/UV $254+366$ (0.2 mm, Macherey-Nagel GmbH \& Co. KG, Düren, Germany) plates, and spots were visualized with $10 \%$ vanillin-sulfuric acid reagent. All other chemicals, reagents, and solvents were of analytical grades.

\subsection{Source of Plant Material}

The fruits of $A$. tsao-ko were purchased in February 2012 from the Seoul Yangnyeong Market (Seoul, Korea) and authenticated by the corresponding authors (Prof., J.S.O.). A voucher specimen (G47) has been deposited in the Herbarium at the College of Pharmacy, Dankook University, Korea.

\subsection{Extraction and Isolation of Compounds}

The dried fruits of $A$. tsao-ko $(5.0 \mathrm{~kg})$ were extracted twice with $80 \%$ ethanol $(36 \mathrm{~L})$ at room temperature as around $21-25^{\circ} \mathrm{C}$ for 2 days, which yielded the ethanolic extract (219 g). The ethanolic extract was then suspended in $\mathrm{H}_{2} \mathrm{O}$ and partitioned successively with $\mathrm{CH}_{2} \mathrm{Cl}_{2}(2 \times 5 \mathrm{~L})$, ethyl acetate $(2 \times 5 \mathrm{~L})$, and $n$-butyl alcohol $(2 \times 5 \mathrm{~L})$. The $\mathrm{CH}_{2} \mathrm{Cl}_{2}$ soluble fraction was suspended in $n$-hexane and partitioned with solvent to obtain $50 \%$ $\mathrm{MeOH}(2 \times 5 \mathrm{~L})$. The $50 \% \mathrm{MeOH}$ fraction showed inhibitory activity with an $\mathrm{IC}_{50}$ below $25 \mu \mathrm{g} / \mathrm{mL}$ on NO overproduction, and thus was subjected to further isolation. The $50 \%$ $\mathrm{MeOH}$ fraction (3.5 g) was chromatographed on a silica gel column, using a step-wise gradient solvent system of $n$-hexane-acetone (1:0 to $1: 1, v / v)$ and $\mathrm{CH}_{2} \mathrm{Cl}_{2}-\mathrm{MeOH}$ (5:1 to $1: 1, v / v)$, to yield 13 fractions (G47-4-1 to G47-4-13) according to TLC analysis. Fraction G47-4-8 (1.0 g) was fractionated using MPLC (RediSep ${ }^{\circledR}$ Rf silica gel 100 gram, 75 mL/min, n-hexane- $\left.\mathrm{CHCl}_{3} ; 90: 10-70: 30, v / v, 100 \mathrm{~min}\right)$ to afford subfraction G47-8-1 to G47-8-12. Compound 2 (17.5 mg) was isolated from the above subfraction, G47-8-2, via preparative HPLC (MeCN- $\mathrm{H}_{2} \mathrm{O}, 75: 25$ to 100:0, $\left.v / v, 12 \mathrm{~mL} / \mathrm{min}, 40 \mathrm{~min}\right)$. Subsequent purification of G47-8-6 with the same HPLC conditions $\left(\mathrm{MeCN}-\mathrm{H}_{2} \mathrm{O}, 70: 30\right.$ to 100:0, $/ 2$, $12 \mathrm{~mL} / \mathrm{min}$, $40 \mathrm{~min}$ ) resulted in compounds $1(38.6 \mathrm{mg})$ and $3(18.1 \mathrm{mg})$. Fraction G47-8-11 (0.8 g) was subjected to further chromatographic separation on a Sephadex LH-20 column and eluted with a step-wise gradient of $\mathrm{CH}_{2} \mathrm{Cl}_{2}-\mathrm{MeOH}(80: 1$ to 10:1, v/v), to yield compounds 4 (7.8 mg), 5 (3.1 mg), and 6 (4.5 mg) based on TLC. The isolation flow map and chemical structures of the six monoterpenoids isolated from the fruits of $A$. tsao-ko are shown in Figure 1.

\subsubsection{Tsaokoin (1)}

Pale brown oil; $[\alpha]_{\mathrm{D}}^{25}-1.7^{\circ}\left(\mathrm{c} 0.3, \mathrm{CH}_{2} \mathrm{Cl}_{2}\right)$; UV $\left(\mathrm{CH}_{3} \mathrm{OH}\right) \lambda_{\max }(\log \varepsilon) 233(4.1) \mathrm{nm} ;{ }^{1} \mathrm{H}$ NMR (700 MHz, CDCl 3 ) $\delta 9.42(1 \mathrm{H}, \mathrm{s}, \mathrm{H}-10), 6.66(1 \mathrm{H}$, brs, H-3), $4.06(1 \mathrm{H}, \mathrm{t}$-like, $J=4.9 \mathrm{~Hz}$, 
H-5), 2.99 (1H, d, J = 7.0 Hz, H-1), 2.54 (1H, td, J = 18.2, 4.9 Hz, H-4), 2.44 (1H, m, H-6), 2.12 $\left(1 \mathrm{H}, \mathrm{m}, \mathrm{H}_{\mathrm{a}}-9\right), 1.80(2 \mathrm{H}, \mathrm{m}, \mathrm{H}-8), 1.57(2 \mathrm{H}, \mathrm{m}, \mathrm{H}-7), 1.43\left(1 \mathrm{H}, \mathrm{m}, \mathrm{H}_{\mathrm{b}}-9\right) ;{ }^{13} \mathrm{C}$ NMR data, see Table 1; ESI-MS (positive ion mode): $m / z 167[\mathrm{M}+\mathrm{H}]^{+}$.

\subsection{2. (3S, $4 S, 6 R)-3,6$-Dihydroxy-1-Menthene (2)}

Colorless oil; $[\alpha]_{\mathrm{D}}^{25}+9.3^{\circ}\left(\mathrm{c} 0.4, \mathrm{CH}_{3} \mathrm{OH}\right) ;{ }^{1} \mathrm{H}$ NMR $\left(700 \mathrm{MHz}\right.$, methanol- $\left.d_{4}\right) \delta 5.49(1 \mathrm{H}$, s, H-2), 3.94 (1H, brs, H-6), 3.87 (1H, d, J = 9.1 Hz, H-3), $2.14(1 \mathrm{H}, \mathrm{m}, \mathrm{H}-8), 1.79$ (3H, s, H-7), $1.74\left(1 \mathrm{H}, \mathrm{dt}, J=14.0,2.8 \mathrm{~Hz}, \mathrm{H}_{\mathrm{a}}-5\right), 1.61(1 \mathrm{H}, \mathrm{m}, \mathrm{H}-4), 1.41\left(1 \mathrm{H}, \mathrm{td}, J=13.3,4.2 \mathrm{~Hz}, \mathrm{H}_{\mathrm{b}}-5\right)$, $1.00(3 \mathrm{H}, \mathrm{d}, J=7.0 \mathrm{~Hz}, \mathrm{H}-9), 0.85(3 \mathrm{H}, \mathrm{d}, J=7.0 \mathrm{~Hz}, \mathrm{H}-10) ;{ }^{13} \mathrm{C}$ NMR data, see Table 1; ESI-MS (positive ion mode): $m / z 171[\mathrm{M}+\mathrm{H}]^{+}$.

\subsection{3. (1R,3S,4R)-3-Hydroxy Isopulegol (3)}

Pale yellowish oil; $[\alpha]_{\mathrm{D}}^{25}+15.5^{\circ}\left(\mathrm{c} 0.5, \mathrm{CH}_{2} \mathrm{Cl}_{2}\right) ;{ }^{1} \mathrm{H}$ NMR $\left(700 \mathrm{MHz}, \mathrm{CDCl}_{3}\right) \delta 4.94$ $\left(1 \mathrm{H}, \mathrm{s}, \mathrm{H}_{\mathrm{a}}-9\right), 4.90\left(1 \mathrm{H}, \mathrm{s}, \mathrm{H}_{\mathrm{b}}-9\right), 3.84(1 \mathrm{H}, \mathrm{td}, \mathrm{J}=10.5,4.9 \mathrm{~Hz}, \mathrm{H}-3), 2.09$ (1H, ddd, J = 13.3, 4.2, $\left.2.8 \mathrm{~Hz}, \mathrm{H}_{\mathrm{a}}-2\right), 1.91(1 \mathrm{H}, \mathrm{m}, \mathrm{H}-4), 1.76(3 \mathrm{H}, \mathrm{s}, \mathrm{H}-10), 1.71\left(2 \mathrm{H}, \mathrm{m}, \mathrm{H}_{\mathrm{a}}-5\right), 1.66$ (1H, ddd, $\left.J=14.0,6.3,2.8 \mathrm{~Hz}, \mathrm{H}_{\mathrm{a}}-6\right), 1.57\left(1 \mathrm{H}, \mathrm{ddd}, J=13.3,7.0,4.2 \mathrm{~Hz}, \mathrm{H}_{\mathrm{b}}-5\right), 1.43(1 \mathrm{H}, \mathrm{td}, J=14.0$, $\left.4.2 \mathrm{~Hz}, \mathrm{H}_{\mathrm{b}}-6\right), 1.36\left(1 \mathrm{H}, \mathrm{dd}, J=12.6,11.2 \mathrm{~Hz}, \mathrm{H}_{\mathrm{b}}-2\right), 1.30(3 \mathrm{H}, \mathrm{s}, \mathrm{H}-7) ;{ }^{13} \mathrm{C}$ NMR data, see Table 1; ESI-MS (positive ion mode): $m / z 171[\mathrm{M}+\mathrm{H}]^{+}$.

\subsection{4. $(1 R, 4 S, 6 S)-1,6-$ Dihydroxy-2-Menthene (4)}

Pale yellowish oil; $[\alpha]_{\mathrm{D}}^{25}+5.1^{\circ}\left(\mathrm{c} 0.1, \mathrm{CH}_{2} \mathrm{Cl}_{2}\right){ }^{1}{ }^{1} \mathrm{H} \mathrm{NMR}\left(700 \mathrm{MHz}, \mathrm{CDCl}_{3}\right) \delta 5.71(2 \mathrm{H}$, overlap, H-2, 3), 3.49 (1H, brd, J = 12.6 Hz, H-6), $2.10(1 \mathrm{H}, \mathrm{m} \mathrm{H}-4), 1.81\left(1 \mathrm{H}, \mathrm{m} \mathrm{H}_{\mathrm{b}}-5\right), 1.70$ (1H, m H-8), $1.40\left(1 \mathrm{H}, \mathrm{m} \mathrm{H}_{\mathrm{b}}-5\right), 1.36$ (3H, s H-7), $0.94(3 \mathrm{H}, \mathrm{d}, J=7.0 \mathrm{~Hz}, \mathrm{H}-9), 0.91$ (3H, d, $J=7.0 \mathrm{~Hz}, \mathrm{H}-10) ;{ }^{13} \mathrm{C}$ NMR data, see Table 1 ; ESI-MS (positive ion mode): $m / z 171[\mathrm{M}+\mathrm{H}]^{+}$.

\subsubsection{3,7-Dimethyl-2-Octene-1,8-Diol (5)}

Colorless oil; ${ }^{1} \mathrm{H}$ NMR $\left(700 \mathrm{MHz}, \mathrm{CDCl}_{3}\right) \delta 5.43(1 \mathrm{H}, \mathrm{t}, J=6.7 \mathrm{~Hz}, \mathrm{H}-2), 4.17(2 \mathrm{H}, \mathrm{d}$, $J=6.3 \mathrm{~Hz}, \mathrm{H}-1), 3.52\left(1 \mathrm{H}, \mathrm{dd}, J=10.5,6.3 \mathrm{~Hz}, \mathrm{H}_{\mathrm{a}}-8\right), 3.46\left(1 \mathrm{H}, \mathrm{dd}, J=9.8,6.3 \mathrm{~Hz}, \mathrm{H}_{\mathrm{b}}-8\right), 2.05$ (2H, m, H-4), 1.69 (3H, s, H-9), 1.66 (1H, s, H-7), 1.52 (1H, m, Ha -5$), 1.42\left(1 \mathrm{H}, \mathrm{m} \mathrm{H}_{\mathrm{a}}-6\right), 1.38$ $\left(1 \mathrm{H}, \mathrm{m} \mathrm{H}_{\mathrm{b}}-5\right), 1.11\left(1 \mathrm{H}, \mathrm{s} \mathrm{H}_{\mathrm{b}}-6\right), 0.94(3 \mathrm{H}, \mathrm{d}, J=7.0 \mathrm{~Hz}, \mathrm{H}-10) ;{ }^{13} \mathrm{C}$ NMR data, see Table 1; ESI-MS (positive ion mode): $m / z 173[\mathrm{M}+\mathrm{H}]^{+}$.

\subsubsection{8-Oxogeraniol (6)}

Colorless oil; ${ }^{1} \mathrm{H}$ NMR $\left(700 \mathrm{MHz}, \mathrm{CDCl}_{3}\right) \delta 9.32(1 \mathrm{H}, \mathrm{s}, \mathrm{H}-8), 6.40(1 \mathrm{H}, \mathrm{t}, J=7.0 \mathrm{~Hz}$, H-6), $5.39(1 \mathrm{H}, \mathrm{t}, J=7.0 \mathrm{~Hz}, \mathrm{H}-2), 4.12(2 \mathrm{H}, \mathrm{d}, J=7.0 \mathrm{~Hz}, \mathrm{H}-1), 2.43(2 \mathrm{H}, \mathrm{dd}, J=15.4,7.7 \mathrm{~Hz}$, $\mathrm{H}-5), 2.16(2 \mathrm{H}, \mathrm{t}, J=7.7 \mathrm{~Hz}, \mathrm{H}-4), 1.68(3 \mathrm{H}, \mathrm{s}, \mathrm{H}-10), 1.63(3 \mathrm{H}, \mathrm{s}, \mathrm{H}-9) ;{ }^{13} \mathrm{C}$ NMR data, see Table 1; ESI-MS (positive ion mode): $m / z 169[\mathrm{M}+\mathrm{H}]^{+}$.

\subsection{Anti-Inflammatory Activities}

\subsubsection{Cell Culture Conditions}

Mouse RAW264.7 macrophage cells (TIB-71) were maintained in Dulbecco's modified Eagle medium (DMEM) supplemented with 10\% fetal bovine serum (FBS), $100 \mathrm{U} / \mathrm{mL}$ penicillin, and $0.1 \mathrm{mg} / \mathrm{mL}$ streptomycin in a humidified incubator with $5 \% \mathrm{CO}_{2}$ at $37^{\circ} \mathrm{C}$.

\subsubsection{Measurement of LPS-Induced NO Production and MTT Assay for Cell Viability}

The Griess reaction was performed to measure the concentration of nitrite in the medium as an indicator of NO production. RAW264.7 macrophage cells were cultured in a 96-well plate after seeding at a density of $4 \times 10^{5}$ cells/well for $24 \mathrm{~h}$ in DMEM supplemented with $10 \%$ FBS, and stimulated with or without LPS $(1 \mu \mathrm{g} / \mathrm{mL}$, Sigma Aldrich, St. Louis, MO, USA) in the presence or absence of the compounds. After $24 \mathrm{~h}$ of incubation at $37{ }^{\circ} \mathrm{C}, 5 \% \mathrm{CO}_{2}$, the cell supernatant was reacted with equal volumes of Griess reagent solutions to determine nitrite production. Absorbance was measured with a microplate reader (Molecular Devices, Sanjose, CA, USA) at $540 \mathrm{~nm}$. Cell viability was confirmed via MTT (Duchefa Biochemie, Haarlem, The Netherlands) assay. The supernatant was 
removed and medium containing MTT solution $(5 \mathrm{mg} / \mathrm{mL}$ in phosphate-buffered saline) was added to each well and incubated for $2 \mathrm{~h}$. The medium was removed, and $100 \mu \mathrm{L}$ of dimethyl sulfoxide (Duchefa Biochemie, Haarlem, The Netherlands) was added to each well to dissolve the purple formazan product to obtain a colored solution. Absorbance was measured at $540 \mathrm{~nm}$ with a microplate reader.

\subsubsection{Reverse Transcription-Polymerase Chain Reaction (RT-PCR)}

RAW264.7 cells, plated in 6-well plates $\left(1 \times 10^{6}\right.$ cells/well), were treated with compound $4(10,50$, and $100 \mu \mathrm{M})$ for $1 \mathrm{~h}$ prior to LPS, and stimulated with $1 \mu \mathrm{g} / \mathrm{mL}$ LPS or remained unstimulated for $24 \mathrm{~h}$. Total RNA was isolated using TRIzol ${ }^{\circledR}$ reagent (Invitrogen, Carlsbad, CA, USA). RNA ( $1 \mu \mathrm{g})$ was used as a template for each reverse-transcribed using a SuperScript ${ }^{\circledR}$ III First-Strand Synthesis System (Invitrogen, Carlsbad, CA, USA). Polymerase chain reaction was performed at $95^{\circ} \mathrm{C}$ for $5 \min (1$ cycle $) ; 95^{\circ} \mathrm{C}$ for $30 \mathrm{~s}, 55^{\circ} \mathrm{C}$ for $40 \mathrm{~s}$ and $72{ }^{\circ} \mathrm{C}$ for $1 \mathrm{~min}$ (30 cycles); and final extension at $72{ }^{\circ} \mathrm{C}$ for $10 \mathrm{~min}$. The primers for PCR were synthesized by Bioneer Corporation (Daejeon, Korea). Glyceraldehyde 3-phosphate dehydrogenase (GAPDH, housekeeping gene) was used as an internal reference control. The PCR primer sequences are shown in Table 3. The bands of interest were quantified using the ChemiDoc XRS system and Quantity One software (Bio-Rad Laboratories, Hercules, CA, USA).

Table 3. Primer sequence used to detect cytokine gene expression.

\begin{tabular}{|c|c|c|}
\hline Gene & \multicolumn{2}{|c|}{ Primer Sequences } \\
\hline \multirow{2}{*}{ iNOS } & forward & 5'-GAGTTCGAGACTTCTGTGA-3' \\
\hline & reverse & 5'-GGCGATCTGGTAGTAGTAG-3' \\
\hline \multirow{2}{*}{ IL-1 $\beta$} & forward & 5'-CTTTGAAGAAGAGCCCATCC-3' \\
\hline & reverse & 5’ TTTGTCGTTGCTTGGTTCTC 3' \\
\hline \multirow{2}{*}{ IL-6 } & forward & 5'-CACTTCACAAGTCGGAGGCTT-3' \\
\hline & reverse & 5'-GCAAGTGCATCATCGTTGTTC-3' \\
\hline \multirow{2}{*}{ GAPDH } & forward & 5'-CAGGTAAACTCAGGAGAGTG-3' \\
\hline & reverse & 5'-GTAGACTCCACGACATACTC-3' \\
\hline
\end{tabular}

\subsubsection{Western Blot Analysis}

RAW264.7 cells, plated in 6-well plates $\left(1 \times 10^{6}\right.$ cells / well $)$, were treated with compound $4(10,50$, and $100 \mu \mathrm{M})$. Next, the cells were resuspended and lysed in RIPA buffer (Sigma Aldrich, St. Louis, MO, USA) including protease inhibitors (Sigma Aldrich, St. Louis, MO, USA). The cell lysates were clarified via centrifugation at $15,000 \times \mathrm{g}$ for $30 \mathrm{~min}$ at $4{ }^{\circ} \mathrm{C}$, and the lysates were subjected to western blot analysis as previously described [33]. Protein expression was analyzed via immunoblotting with antibodies against anti-iNOS (cat. no. ab3523; dilution, 1:500, Abcam, Cambridge, UK) and $\beta$-actin (cat. no. 5125; dilution, 1:1000, Cell Signaling Technology, Danvers, MA, USA). All western blot results are representative of at least three independent experiments. The bands of interest were quantified using the imageJ software.

\subsubsection{Statistical Analysis}

Data are expressed as mean \pm standard deviation (SD). The results were analyzed for statistical significance using Student's $t$-test and one-way analysis of variance. Values of ${ }^{*} p<0.05,{ }^{* *} p<0.01$ were considered statistically significant.

\section{Conclusions}

In this study, we performed phytochemical and biological activity analysis of monoterpene constituents isolated from $A$. tsao-ko fruits. The isolated compounds constituted one bicyclic nonane (1), three menthene skeleton monoterpenoids (2-4), and two acyclic monoterpenoids ( 5 and 6 ). To the best of our knowledge, compounds $2-5$ were obtained from the genus Amomum for the first time. Among these compounds, compound $4((1 R, 4 S, 6 S)-1,6-$ 
dihydroxy-2-menthene) exerts the anti-inflammatory effect by inhibiting the NO production via down-regulation of iNOS in LPS-stimulated RAW264.7 cells. This study is the first attempted to reveal the anti-inflammatory effect of compound 4 isolated from $A$. tsao-ko, we also can provide evidence that compound 4 suppressed the expression of pro-inflammatory cytokines, such as IL-1 $\beta$ and IL-6 in LPS-induced macrophages. However, further studies using anti-inflammatory drugs are required to estimate the efficiency of compound 4 on its anti-inflammatory potential. The discovery of these functional monoterpenoids suggests that the fruits of $A$. tsao-ko have medicinal value for treating inflammation and related disorders.

Supplementary Materials: The following are available online at https://www.mdpi.com/2223-7 747/10/2/257/s1, Figure S1: Effect of 4 on cell viability and NO production, Figure S2: ${ }^{1} \mathrm{H}$ NMR spectrum of 1, Figure S3: ${ }^{13} \mathrm{C}$ NMR spectrum of $\mathbf{1}$, Figure S4: ${ }^{1} \mathrm{H}$ NMR spectrum of 2, Figure S5: ${ }^{13} \mathrm{C}$ NMR spectrum of 2, Figure S6: ${ }^{1} \mathrm{H}$ NMR spectrum of 3, Figure S7: ${ }^{13} \mathrm{C}$ NMR spectrum of 3, Figure S8: ${ }^{1} \mathrm{H}$ NMR spectrum of 4, Figure S9: ${ }^{13} \mathrm{C}$ NMR spectrum of 4, Figure S10: ${ }^{1} \mathrm{H}$ NMR spectrum of 5, Figure S11: ${ }^{13} \mathrm{C}$ NMR spectrum of 5, Figure S12: ${ }^{1} \mathrm{H}$ NMR spectrum of 6, Figure S13: ${ }^{13} \mathrm{C}$ NMR spectrum of 6 .

Author Contributions: Conceptualization, S.S.H. and J.S.O.; formal analysis, J.E.L., Y.W.J., J.-H.P., W.J. and J.A.L.; investigation, J.E.L., Y.W.J. and J.A.L.; writing—original draft preparation, S.S.H., E.-K.A. and C.W.C.; writing-review and editing, S.S.H., E.-K.A. and J.S.O.; supervision, S.S.H. and J.S.O.; project administration, J.S.O.; and funding acquisition, J.S.O. All authors have read and agreed to the published version of the manuscript.

Funding: This work was supported by the "Cooperative Research Program for Agriculture Science and Technology Development (Project No. PJ01323301)" Rural Development Administration, Korea.

Conflicts of Interest: The authors declare no conflict of interest.

\section{References}

1. Cheuka, P.M.; Mayoka, G.; Mutai, P.; Chibale, K. The role of natural products in drug discovery and development against neglected tropical diseases. Molecules 2017, 22, 58. [CrossRef] [PubMed]

2. Newman, D.J.; Cragg, G.M. Natural products as sources of new drugs over the nearly four decades from 01/1981 to 09/2019. J. Nat. Prod. 2002, 83, 770-803. [CrossRef] [PubMed]

3. Xia, Y.M.; Kress, W.J.; Prince, L.M. Phylogenetic analyses of Amomum (Alpinioideae: Zingiberaceae) using ITS and matK DNA sequence data. Syst. Bot. 2004, 29, 334-344. [CrossRef]

4. Kaewsri, W.; Paisooksantivatana, Y. Morphology and palynology of Amomum Roxb. in Thailand. Gard. Bull. 2007, 59, $105-112$.

5. Lee, S.; Lee, J.C.; Subedi, L.; Cho, K.H.; Kim, S.Y.; Park, H.J.; Kim, K.H. Bioactive compounds from the seeds of Amomum tsaoko Crevost et Lemaire, a Chinese spice as inhibitors of sphingosine kinases, SPHK1/2. RSC Adv. 2019, 9, 33957-33968. [CrossRef]

6. Sim, S.; Tan, S.K.; Kohlenberg, B.; Braun, N.A. Amomum tsao-ko-Chinese black cardamom: Detailed oil composition and comparison with two other cardamom species. Nat. Prod. Commun. 2019, 14, 1934578X19857675. [CrossRef]

7. Hong, S.S.; Lee, J.H.; Choi, Y.H.; Jeong, W.; Ahn, E.K.; Lym, S.H.; Oh, J.S. Amotsaokonal A-C, benzaldehyde and cycloterpenal from Amomum tsao-ko. Tetrahedron Lett. 2015, 56, 6681-6684. [CrossRef]

8. Liu, H.; Yan, Q.; Zou, D.; Bu, X.; Zhang, B.; Ma, X.; Leng, A.; Zhang, H.; Li, D.; Wang, C. Identification and bioactivity evaluation of ingredients from the fruits of Amomum tsaoko Crevost et Lemaire. Phytochem. Lett. 2018, 28, 111-115. [CrossRef]

9. Zhang, T.T.; Lu, C.L.; Jiang, J.G. Neuroprotective and anti-inflammatory effects of diphenylheptanes from the fruits of Amomum tsaoko, a Chinese spice. Plant Foods Hum. Nutr. 2016, 71, 450-453. [CrossRef]

10. Zhang, T.T.; Lu, C.L.; Jiang, J.G. Antioxidant and anti-tumour evaluation of compounds identified from fruit of Amomum tsaoko Crevost et Lemaire. J. Funct. Foods 2015, 18, 423-431. [CrossRef]

11. Zhang, T.T.; Lu, C.L.; Jiang, J.G. Bioactivity evaluation of ingredients identified from the fruits of Amomum tsaoko Crevost et Lemaire, a Chinese spice. Food Funct. 2014, 5, 1747-1754. [CrossRef] [PubMed]

12. Moon, S.S.; Lee, J.Y.; Cho, S.C. Isotsaokoin, an antifungal agent from Amomum tsao-ko. J. Nat. Prod. 2004, 67, 889-891. [CrossRef]

13. He, X.F.; Wang, H.M.; Geng, C.A.; Hu, J.; Zhang, X.M.; Guo, Y.Q.; Chen, J.J. Amomutsaokols A-K, diarylheptanoids from Amomum tsao-ko and their $\alpha$-glucosidase inhibitory activity. Phytochemistry 2020, 177, 112418. [CrossRef] [PubMed]

14. He, X.F.; Zhang, X.K.; Geng, C.A.; Hu, J.; Zhang, X.M.; Guo, Y.Q.; Chen, J.J. Tsaokopyranols A-M, 2,6-epoxydiarylheptanoids from Amomum tsao-ko and their $\alpha$-glucosidase inhibitory activity. Bioorg. Chem. 2020, 96, 103638. [CrossRef] [PubMed]

15. Kim, J.G.; Jang, H.; Le, T.P.L.; Hong, H.R.; Lee, M.K.; Hong, J.T.; Lee, D.; Hwang, B.Y. Pyranoflavanones and pyranochalcones from the fruits of Amomum tsao-ko. J. Nat. Prod. 2019, 82, 1886-1892. [CrossRef] 
16. Chen, L.; Deng, H.; Cui, H.; Fang, J.; Zuo, Z.; Deng, J.; Li, Y.; Wang, X.; Zhao, L. Inflammatory responses and inflammationassociated diseases in organs. Oncotarget 2018, 9, 7204-7218. [CrossRef]

17. Zamora, R.; Vodovotz, Y.; Billiar, T.R. Inducible nitric oxide synthase and inflammatory diseases. Mol. Med. 2000, 6, 347-373. [CrossRef]

18. Dinarello, C.A. Proinflammatory cytokines. Chest 2000, 118, 503-508. [CrossRef]

19. Song, Q.S.; Teng, R.W.; Liu, X.K.; Yang, C.R. Tsaokoin, a new bicyclic nonane from Amomum tsao-ko. Chin. Chem. Lett. 2001, 12, 227-230.

20. Liu, J.F.; Li, H.J.; Wang, L.X.; Liu, M.Q.; Bi, Y.F.; Zhang, Y.B. Two new monoterpenes from the fruits of Illicium lanceolatum. Molecules 2013, 18, 11866-11872. [CrossRef]

21. Pardo-Novoa, J.C.; Arreaga-González, H.M.; Gómez-Hurtado, M.A.; Rodríguez-García, G.; Cerda-García-Roja, C.M.; JosephNathan, P.; del Río, R.E. Absolute configuration of menthene derivatives by vibrational circular dichroism. J. Nat. Prod. 2016, 79, 2570-2579. [CrossRef] [PubMed]

22. Fkyerat, A.; Tabacchi, R. Enantioselective preparation of 1-hydroxy neoisopulegol and 1-hydroxy neoisomenthol. Tetrahedron: Asymmetry 1997, 8, 2231-2236. [CrossRef]

23. De Pascual Teresa, J.; Torres, C.; Gonzalez, M.S.; Grande, M.; Bellido, I.S. $\Delta^{5}$-Dehydro-1-hydroxycarvomenthols from the essential oil of Chenopodium multifidum. Phytochemistry 1983, 22, 2749-2751. [CrossRef]

24. Knapp, H.; Straubinger, M.; Fornari, S.; Oka, N.; Watanabe, N.; Winterhalter, P. (S)-3,7-Dimethyl-5-octene-1,7-diol and related oxygenated monoterpenoids from petals of Rosa damascena Mill. J. Agric. Food Chem. 1998, 46, 1966-1970. [CrossRef]

25. Elsharif, S.A.; Buettner, A. Structure-odor relationship study on geraniol, nerol, and their synthesized oxygenated derivatives. J. Agric. Food Chem. 2018, 66, 2324-2333. [CrossRef] [PubMed]

26. Choi, C.W.; Shin, J.Y.; Seo, C.; Hong, S.S.; Ahn, E.K.; Jung, Y.H.; Oh, J.S. In vitro anti-inflammatory activity of the components of Amomum tsao-ko in murine macrophage raw 264.7 cells. Afr. J. Tradit. Complement. Altern. Med. 2018, 15, 26-34. [CrossRef]

27. Costa, E.D.; Lemos, V.S.; Rezende, B.A.; Cortes, S.F. Neuronal nitric oxide synthase in vascular physiology and diseases. Front. Physiol. 2016, 7, 206. [CrossRef] [PubMed]

28. Hong, S.S.; Lee, S.A.; Han, X.H.; Hwang, J.S.; Lee, C.; Lee, D.; Hong, J.T.; Kim, Y.; Lee, H.; Hwang, B.Y. ent-Kaurane diterpenoids from Isodon japonicas. J. Nat. Prod. 2008, 71, 1055-1058. [CrossRef]

29. Shin, J.Y.; Kang, J.S.; Byun, H.Y.; Ahn, E.K. Regulatory effects and molecular mechanism of Trigonostemon reidioides on lipopolysaccharide-induced inflammatory responses in RAW264.7 cells. Mol. Med. Rep. 2017, 16, 5137-5142. [CrossRef]

30. Sur, B.; Kim, M.; Villa, T.; Oh, S. Benzylideneacetophenone derivative alleviates arthritic symptoms via modulation of the MAPK signaling pathway. Molecules 2020, 25, 3319. [CrossRef]

31. Mastinu, A.; Bonini, S.A.; Rungratanawanich, W.; Aria, F.; Marziano, M.; Maccarinelli, G.; Abate, G.; Premoli, M.; Memo, M.; Uberti, D. Gamma-oryzanol prevents LPS-induced brain inflammation and cognitive impairment in adult mice. Nutrients 2019, 11, 728. [CrossRef] [PubMed]

32. Shin, J.S.; Ryu, S.; Jang, D.S.; Cho, Y.W.; Chung, E.K.; Lee, K.T. Amomum tsao-ko fruit extract suppresses lipopolysaccharideinduced inducible nitric oxide synthase by inducing heme oxygenase-1 in macrophages and in septic mice. Int. J. Exp. Pathol. 2016, 96, 395-405. [CrossRef] [PubMed]

33. Kim, M.S.; Ahn, E.K.; Hong, S.S.; Oh, J.S. 2,8-Decadiene-1,10-diol inhibits lipopolysaccharide-induced inflammatory responses through inactivation of mitogen-activated protein kinase and nuclear factor- $\mathrm{kB}$ signaling pathway. Inflammation 2016, 39, 583-591. [CrossRef] [PubMed] 